\title{
Do all elements of intellectual capital matter for organizational performance? Evidence from Russian context
}

\author{
Tatiana Andreeva \\ Maynooth University, School of Business, Maynooth, Ireland and \\ St Petersburg University Graduate School of Management, \\ St Petersburg, Russia, and \\ Tatiana Garanina \\ St Petersburg University Graduate School of Management, \\ St Petersburg, Russia
}

\begin{abstract}
Purpose - Intellectual capital (IC) has been argued to be the key element of value creation in contemporary economies and this argument has been widely supported by empirical research, but mainly based on data from developed markets. The question of how IC and its elements work in other contexts remains under-researched and the limited empirical evidence that exists contradicts the conclusions drawn from developed countries. The purpose of this paper is to provide empirical insight into the relationship between three main elements of IC (human, relational and structural) and organizational performance in the particular context of Russian manufacturing companies.

Design/methodology/approach - The sample comprises 240 Russian manufacturing companies. The data are collected by survey using the scales already validated in the international context. The authors use a two-step analysis - factor and regression analyses - to answer the research questions. Findings - The findings demonstrate that structural and human capitals positively influence organizational performance, explaining a quarter of its variation, while relational capital does not.

Practical implications - The core managerial implication of this study is that developing structural capital is of particular importance for Russian manufacturing companies.

Originality/value - The paper contributes to further development of IC theory by investigating its application in the new institutional and cultural context of Russia.

Keywords Russia, Organizational performance, Intellectual capital, Relational capital,

Human capital, Structural capital

Paper type Research paper

\section{Introduction}

Many authors argue that in the twenty-first century the value of a company is created mainly by intangible assets (Edvinsson and Malone, 1997; Furman et al., 2002; Guthrie, 2001; Sveiby, 1997). People and their knowledge, expertise, ability to innovate, licensing agreements, organizational culture and other intangible assets have been widely demonstrated to be the most important assets for a company's development. Hence, the main competence of companies in the knowledge-based economy becomes the ability to manage their intellectual capital (IC).

The authors contributed equally to this work.

The authors would like to acknowledge financial support from St Petersburg University as part of the project "Support of Research Projects of Graduate School of Management SPbU Academic Staff" (project No. 16.23.1704.2014).
\end{abstract}

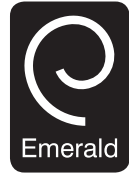

Journal of Intellectual Capital Vol. 17 No. 2, 2016 pp. 397-412
C Emerald Group Publishing Limited
$1469-1930$ DOI 10.1108/JIC-07-2015-0062 
$\mathrm{JIC}$

17,2

398

But is this true for the emerging markets? Does IC matter much in this context? The economies of many emerging countries depend heavily on natural or other tangible resources. Indeed, resource extraction in the emerging economies more than doubled between 1985 and 2005, leading to a situation where more than one-third of all the world's natural resources are currently extracted in the emerging economies and with their GDP consequently highly dependent on this sector (Dittrich et al., 2011). The quality of the human capital available in the emerging economies' labor markets may also differ from that in developed markets. Emerging markets' executives frequently complain about the gap between the skills and knowledge learnt in domestic universities and the needs of industry (Economist, 2008). At the same time, emerging countries suffer from a "brain drain," as the most skilled and experienced candidates leave for developed countries who seek for talents worldwide (PricewaterhouseCoopers, 2014). Finally, companies in emerging markets are frequently described as lacking managerial competences and modern management processes and practices (Economist, 2008).

All these considerations indicate that the relevance of IC and its contribution to the performance of firms in emerging markets might differ from the relationships established in the mainstream IC literature. Indeed, the limited empirical evidence on IC in emerging markets contradicts the findings drawn from developed countries (e.g. Garanina, 2011). In line with recent calls for deeper contextualization of the theories developed in the West (Michailova, 2011; May and Stewart, 2013), we suggest that a better understanding of the role of IC in emerging markets may help to enrich and advance IC theory. It will also help managers of both multi-national companies operating in the context of emerging markets and local companies themselves to run their companies efficiently.

However, the question of how IC and its elements work in emerging markets remains under-researched and more empirical research is needed in this context in order to enhance IC theory. At the same time emerging economies, although bracketed together, differ significantly in the key variables of the political, institutional, cultural and economic context that create the preconditions for development and utilization of intangibles (PricewaterhouseCoopers, 2014). Therefore, in order to meaningfully interpret the findings of this much-needed empirical research, focus should be on a particular country and its specific context.

This paper aims to address these needs by analyzing how various elements of IC affect organizational performance in the particular context of Russian manufacturing companies. It is based on a sample of 240 manufacturing companies from different regions of Russia and uses company survey-based measures of IC. The findings contribute to further development of IC theory by investigating their application in a different institutional and cultural context (in line with May and Stewart, 2013).

\section{The relationship between IC elements and organizational performance in Russia: what do we know so far?}

The very definition of IC implies that it is a valuable resource that brings the company additional economic value (FASB, 2007). Therefore, it has been proposed that IC has a positive impact on organizational performance (Marr and Roos, 2005) and this idea had been widely tested in the context of developed countries (e.g. Bontis, 1998; Subramaniam and Youndt, 2005). A recent review of this research stream indeed confirms that IC positively affects various organizational outcomes and innovation performance in particular (Inkinen, 2015). Moreover, existing studies suggest that different elements of IC may interact with each other, enhancing the joint impact on performance. Extending this 
idea, Inkinen (2015) suggests that human capital is the most important of the elements of Evidence from IC, as it helps to generate relational and structural capital.

Do these relationships hold across different contexts? In particular, how do they work in the context of Russia? Table I summarizes all the studies on the relationship between the different elements of IC and the performance of Russian companies that we were able to identify.

Table I demonstrates that the studies of the relationships between IC and organizational performance in the Russian context are limited in both number and scope and rely chiefly on the value-added intellectual coefficient (VAIC) method to evaluate IC elements, or on IC proxies that are also based on VAIC methodology. Table I also demonstrates that the findings of these studies coincide only in one way: they all suggest

\begin{tabular}{|c|c|c|c|c|c|c|c|}
\hline \multirow[b]{2}{*}{ No. } & \multirow[b]{2}{*}{ Authors } & \multirow{2}{*}{$\begin{array}{l}\text { Sample: industry } \\
\text { sector and size }\end{array}$} & \multirow{2}{*}{$\begin{array}{l}\text { Methods } \\
\text { used to } \\
\text { evaluate IC }\end{array}$} & \multirow{2}{*}{$\begin{array}{l}\text { Proxies used } \\
\text { to evaluate } \\
\text { organizational } \\
\text { performance }\end{array}$} & \multicolumn{3}{|c|}{$\begin{array}{l}\text { Findings: the impact } \\
\text { of IC elements on } \\
\text { performance }\end{array}$} \\
\hline & & & & & $\mathrm{HC}$ & $\mathrm{RC}$ & $\mathrm{SC}$ \\
\hline 1 & $\begin{array}{l}\text { Tovstiga and } \\
\text { Tulugurova } \\
\text { (2007) }\end{array}$ & $\begin{array}{l}20 \text { innovative } \\
\text { companies from } \\
\text { St Petersburg and } \\
\text { its region }\end{array}$ & Survey & $\begin{array}{l}\text { Internal and external } \\
\text { organizational } \\
\text { indicators }\end{array}$ & ++ & $\mathrm{n} / \mathrm{a}$ & + \\
\hline 2 & $\begin{array}{l}\text { Bayburina and } \\
\text { Golovko (2008) }\end{array}$ & $\begin{array}{l}19 \text { companies, } \\
\text { various industry } \\
\text { sectors }\end{array}$ & $\begin{array}{l}\text { Method of } \\
\text { proxy } \\
\text { indicators }\end{array}$ & $\begin{array}{l}\text { Intellectual } \\
\text { Enterprise value }\end{array}$ & ++ & $\mathrm{n} / \mathrm{a}$ & + \\
\hline 3 & Garanina (2011) & $\begin{array}{l}43 \text { companies from } \\
\text { extractive industry, } \\
\text { power engineering, } \\
\text { communication } \\
\text { services and } \\
\text { metallurgy }\end{array}$ & $\begin{array}{l}\text { Method of } \\
\text { proxy } \\
\text { indicators }\end{array}$ & Price per share & ++ & $+/ \mathrm{no}^{\mathrm{a}}$ & + \\
\hline 4 & $\begin{array}{l}\text { Bykova and } \\
\text { Molodchik } \\
\text { (2011) }\end{array}$ & $\begin{array}{l}115 \text { companies of } \\
\text { Perm region, no } \\
\text { information on the } \\
\text { industry sector }\end{array}$ & VAIC $^{b}$ & Revenue growth rate & + & $\mathrm{n} / \mathrm{a}$ & + \\
\hline 5 & $\begin{array}{l}\text { Molodchik and } \\
\text { Nursubina } \\
\text { (2012) }\end{array}$ & $\begin{array}{l}\text { Russia (60 } \\
\text { companies) and USA } \\
\text { (143 companies), no } \\
\text { information on the } \\
\text { industry sector }\end{array}$ & $\begin{array}{l}\text { Method of } \\
\text { proxy } \\
\text { indicators }\end{array}$ & $\begin{array}{l}\text { Share of new } \\
\text { products in product } \\
\text { line (innovation } \\
\text { performance } \\
\text { indicator) }\end{array}$ & - & + & + \\
\hline 6 & $\begin{array}{l}\text { Tomchuk } \\
\text { et al. (2013) }\end{array}$ & $\begin{array}{l}15 \text { companies of } \\
\text { Perm region, no } \\
\text { information on the } \\
\text { industry sector }\end{array}$ & VAIC $^{b}$ & Return on sales & + & $\mathrm{n} / \mathrm{a}$ & + \\
\hline
\end{tabular}

Notes: HC, human capital; RC, relational capital; SC, structural capital; ++, a strong positive relationship was found, identified as having higher coefficients in the model compared to other variables; +, a positive relationship was found; - , a negative relationship was found; no, no relationship was found; $\mathrm{n} / \mathrm{a}$, the data on the relationship is not available as this element of the intellectual capital was not included in the model. ${ }^{\text {a}} F$ indings differ between the industries: relational capital is important in telecommunications but insignificant in energetics; ${ }^{b}$ in these studies, the different proxies were used that are not directly comparable with each other. Therefore, their findings identify the positive relationship between IC elements and organizational results, but they do not allow defining which element of IC influences performance the most 
$\mathrm{JIC}$

17,2

400

that structural capital positively affects the performance of Russian companies. The conclusions regarding human and relational capital differ among these studies. Moreover, relational capital is not considered in most of these studies, so we know very little about its impact in Russia.

These inconsistencies between the findings of existing studies might be explained in a number of ways. First, there are the differences in the industries analyzed (Cabrita and Bontis, 2008), or in the methods used to evaluate the elements of IC (F-Jardón and Martos, 2009). Second, most of the existing studies rely on very small samples and therefore have limited predictive power. Third, they mostly used financial proxies for estimating the elements of IC, although such proxies have been criticized as not accurately reflecting the real situation in a company (Coombs and Bierly, 2006). To summarize, the empirical data on which elements of IC are the most important in the Russian context is limited and contradictory and does not allow to meaningfully contextualize the IC concepts. At the same time, some authors argue that Russia represents a specific context where knowledge-based processes work differently in comparison to Western or Japanese companies (Andreeva and Ikhilchik, 2011; May and Stewart, 2013). The next section examines these considerations further.

\section{Putting intangibles in context: the case of Russia}

The need for a deeper appreciation of the contexts in which management research is embedded has been recently highlighted by a number of management scholars (e.g. Johns, 2006; Michailova, 2011), including those who focus on the intangible resources of organizations (Andreeva and Ikhilchik, 2011; May and Stewart, 2013; Sergeeva and Andreeva, forthcoming). For example, the socio-economic and cultural peculiarities of specific regions or countries may create particular circumstances in which some management theories and models may work differently (e.g. Whetten, 2009). Understanding such peculiarities may not only produce more insight into managing indigenous companies, but also inform and extend the mainstream theories (May and Stewart, 2013). However, IC discourse still lacks the studies that explore contextual contingencies in which intangibles develop and function.

Following May and Stewart (2013), we propose that Russia represents an interesting and potentially useful context for IC research that aims to address this gap, because its historical, socio-cultural, economic and political contingencies contrast with the typically studied Western contexts and thus provide a "natural laboratory" (May and Stewart, 2013, p. 149) for such studies. In this section we review some peculiarities of the Russian context from the perspective of different elements of IC.

Human capital is usually defined as the knowledge, skills and experience that employees take with them when leaving (IFAC, 1998). Russia is renowned for the quality and accessibility of its education system, resulting in a high literacy rate and a large proportion of citizens with higher education (OECD, 2012). Therefore, one can assume that the human capital already available to Russian companies from the labor market should be of high quality. However, there are several "buts" to this. First, the economic shifts of the last two decades have led to significant discrepancies between the demand from the business side and the supply provided by the educational system, both in terms of professions and in terms of quality and relevance. Russian companies often complain that the labor market does not provide them with the required qualifications (Clarke and Metalina, 2000; Ardichvili and Dirani, 2005) and they need to invest in their own educational ventures (e.g. corporate universities). These discrepancies are particularly acute for certain professions, such as some 
engineering fields and qualified blue-collar work, as they were not popular among Evidence from young people in recent times. Another concern is the brain drain of the most skilled employees from Russia to developed countries, leads to an even higher lack of talented personnel (Economist, 2008).

Moreover, it is not enough to have skilled employees: they should also be motivated and committed to contributing to their organizations. Unfortunately, as a result of decades of economic instability and drastic changes both at societal and organizational levels, when mass lay-offs, serious delays in payment of salaries and significant reductions in wages were common (Gurkov and Zelenova, 2009; Gurkov et al., 2012b), Russian employees typically show relatively low commitment to their organizations (e.g. May et al., 2011). Further, some researchers have suggested that Russian employees are typically unwilling to share knowledge within their organization (Michailova and Husted, 2003; Michailova and Hutchings, 2006), due both to the belief that knowledge is power and should be kept to themselves and to fear of being dismissed (as once they share their knowledge, they would not be needed any more). Such attitudes put the usefulness to their companies of employees' human capital under question.

All these considerations lead the authors to hypothesize that, unlike in many developed countries (e.g. Inkinen, 2015), human capital would have a relatively low impact on the organizational performance of Russian companies:

H1. The positive relationship between human capital and organizational performance in Russian manufacturing companies is weaker than that of other elements of IC.

Structural (or organizational) capital refers to the knowledge kept within the organization that is represented by the intellectual property objects and infrastructure assets, such as management practices and procedures (IFAC, 1998). Developing both of these components might be problematic in the Russian context. First, the field of protecting property rights in Russia is still at a nascent stage. The process of registering patents is time-consuming and costly and subsequent legal reinforcement procedures are weak; and both these considerations demotivate Russian organizations in officially registering the relevant intellectual property rights (Molodchik and Nursubina, 2012). Second, Russian companies often lack management competences and tend to over-rely on informal management mechanisms (Puffer and McCarthy, 2011). These all lead to deficiencies in internal management processes (e.g. Gurkov et al., 2012a), in particular those that help managing and retaining knowledge within an organization (Andreeva and Ikhilchik, 2011; Andreeva et al., 2015).

These considerations lead the authors to hypothesize that, as with human capital, structural capital will have a relatively low impact on organizational performance in the Russian context:

H2. The positive relationship between structural capital and organizational performance of Russian manufacturing companies is weaker than that of other elements of IC.

Relational capital refers to the additional value embedded in the organization's relationships with customers, suppliers and other stakeholders (IFAC, 1998). The importance of such relationships in the Russian business context has been widely acknowledged in the literature (Ledeneva, 1998; Lonkila, 2011). It could have several reasons. First, the weak legitimacy of formal institutions, or institutional voids, pushes entrepreneurs and managers to seek for other mechanisms for protecting and developing their organizations in the Russian context (Puffer and McCarthy, 2011; McCarthy et al., 2012). Second, the peculiarities of Russian culture that promote the 
$\mathrm{JIC}$

17,2

402

value of personal relations and personal trust fosters situations when personal relationships often precede or even become a prerequisite for business relationships (Salmi and Bäckman, 1999; Michailova and Worm, 2003). All this makes networking an inherent part of doing business in Russia and Russian companies appear to be skilled at it (Puffer and McCarthy, 2011). In other words, one may expect that relational capital would be of particular importance for Russian companies.

These observations lead the authors to hypothesize that relational capital would have a relatively strong impact on organizational performance of Russian companies:

H3. The positive relationship between the relational capital and organizational performance of Russian manufacturing companies is stronger than that of other elements of IC.

\section{Methodology and sample}

The data for this project were collected in January-March 2015 within the frames of the international research project entitled "Managing intellectual capital for organizational performance: do knowledge management practices matter?" As the research questions in this project covered a number of formal management practices, we focussed on companies with at least 100 employees, to ensure that such management practices are formalized in the target companies. Conceptually we were interested in companies from different sectors of the economy; however, we found that in Russia, service companies were typically relatively small in size, especially in the peripheral regions, making it difficult to recruit companies with over 100 employees from the service sector. Targeting both manufacturing and service companies might have resulted in a data set both strongly biased toward the manufacturing sector and being atypical of service companies. At the same time, previous research has suggested that manufacturing and service companies may have different configurations of IC elements that, in turn, might make different contributions to their performance (Kianto et al., 2010). This unbalanced data set would not allow a fair comparison of the two sectors, so we decided to focus on manufacturing companies only.

To ensure relative representativeness and variety of the data, we intended to cover 24 regions of Russia for data collection and target manufacturing companies in 11 sectors (see Tables II and III for the lists of regions and industries, respectively). The publicly available lists of companies in these regions were screened to identify those with more than 100 employees in the 11 target industries. In all, 615 companies were randomly selected from the list of all eligible ones (more or less evenly distributed across industries and regions) and contacted by an external research company by telephone. The person in charge of the human resources, CEO or other top manager was asked to respond to the questionnaire. Confidentiality was emphasized and a summary of the results was promised to the respondents. In all, 240 companies responded to the survey, resulting in a 39 percent response rate. This response rate is quite high for Russia, as Russian companies are typically reluctant to participate in any research due to the culture of information secrecy (Andreeva and Kianto, 2012). Such good results can be explained by the involvement of the external research company whose employees are specially trained in negotiating and "selling" techniques and by the use of telephone interviews (rather than mailing) as a data collection method.

Tables II-IV represent details of the resulting sample. The best represented areas were Moscow and its region (12.5 percent), the Ekaterinburg and Sverdlovsk region (10 percent) and St Petersburg and the Leningrad region (8.8 percent). The largest 


\begin{tabular}{|c|c|c|c|c|}
\hline No. & Region & Number of companies & $\%$ of sample & Evidence from \\
\hline 1 & Moscow and Moscow region & 30 & 12.5 & \\
\hline 2 & Sverdlovsk region & 24 & 10.0 & context \\
\hline 3 & St Petersburg and Leningrad region & 21 & 8.8 & \\
\hline 4 & Tula region & 10 & 4.2 & \\
\hline 5 & Yaroslavl region & 10 & 4.2 & \\
\hline 6 & Nizhny Novgorod region & 10 & 4.2 & 403 \\
\hline 7 & Chuvashia republic & 10 & 4.2 & FUJ \\
\hline 8 & Volgograd region & 10 & 4.2 & \\
\hline 9 & Samara region & 10 & 4.2 & \\
\hline 10 & Krasnodarsky krai & 10 & 4.2 & \\
\hline 11 & Rostov region & 10 & 4.2 & \\
\hline 12 & Chelyabinsk region & 10 & 4.2 & \\
\hline 13 & Krasnoyarsky krai & 10 & 4.2 & \\
\hline 14 & Irkutsk & 10 & 4.2 & \\
\hline 15 & Voronezh region & 9 & 3.8 & \\
\hline 16 & Penza region & 9 & 3.8 & \\
\hline 17 & Perm region & 9 & 3.8 & \\
\hline 18 & Kostroma region & 5 & 2.1 & \\
\hline 19 & Belgorod region & 5 & 2.1 & \\
\hline 20 & Kursk region & 5 & 2.1 & \\
\hline 21 & Uljanovsk region & 5 & 2.1 & \\
\hline 22 & Bashkortostan republic & 5 & 2.1 & \\
\hline 23 & Omsk region & 2 & 0.8 & Table II. \\
\hline \multirow[t]{2}{*}{24} & Lipetsk region & 1 & 0.4 & Regional diversity \\
\hline & Total & 240 & 100.0 & of the sample \\
\hline
\end{tabular}

\begin{tabular}{|c|c|c|c|c|}
\hline No. & Manufacture of & Number of companies & $\%$ of sample & \\
\hline 1 & Machinery and equipment (including electronic machinery & & & \\
\hline & and equipment) & 42 & 17.5 & \\
\hline 2 & Vehicles (transport) & 28 & 11.7 & \\
\hline 3 & Food & 25 & 10.4 & \\
\hline 4 & Consumer goods & 23 & 9.6 & \\
\hline 5 & Rubber and plastic goods & 19 & 7.9 & \\
\hline 6 & Wood processing, wood products, paper, paperboard and articles thereof & 18 & 7.5 & \\
\hline 7 & Chemicals (pharmaceuticals excluded) & 17 & 7.1 & \\
\hline 8 & Publishing and printing & 14 & 5.8 & \\
\hline 9 & Metallurgy & 13 & 5.4 & \\
\hline 10 & $\mathrm{TV}$, radio and telecommunication equipment & 9 & 3.8 & \\
\hline 11 & Metal goods & 8 & 3.3 & \\
\hline 12 & Furniture & 7 & 2.9 & \\
\hline 13 & Coke (carbon), oil products and nuclear fuel & 5 & 2.1 & \\
\hline 14 & Medical and optical equipment, watches & 5 & 2.1 & \\
\hline 15 & Recycling of secondary raw materials & 4 & 1.7 & Table III. \\
\hline 16 & Pharmaceutical products & 2 & 0.8 & Industry sectors \\
\hline 17 & Computers and office equipment & 1 & 0.4 & surveyed \\
\hline
\end{tabular}

\begin{tabular}{lcrr}
\hline Position of respondent & Number of companies & \% of sample \\
\hline Deputy CEO & 93 & 38.8 \\
Other managerial positions & 58 & 24.2 & Table IV. \\
Head of HR department & 56 & 23.3 & Positions of the \\
CEO & 33 & 13.8 & survey respondents \\
\hline
\end{tabular}


$\mathrm{JIC}$

17,2

404

industrial sector was manufacture of machinery and equipment (including electronic machines and equipment, 17.5 percent). Other notable sectors were manufacturing transportation machines (11.7 percent), food manufacturing (10.4 percent) and consumer goods manufacturing (9.6 percent).

Most of the respondents held senior positions (see Table IV), indicating their expertise and key position in the organization, in order to evaluate their companies' current performance and management practices.

\section{Measures}

The problem of measuring the components of IC is difficult and not without controversy. The first approach is based on practitioner-focussed guidelines such as Skandia Navigator (Edvinsson and Malone, 1997) or the Intangible Asset Monitor (Sveiby, 1997) that provide algorithms for defining IC components. Due to the lack of a theoretical basis or uniform approach in identifying and measuring IC indicators, these models cannot be applied to every company and are therefore not applicable for quantitative studies that compare and aggregate data from multiple organizations.

The second approach suggests measuring IC components with proxies: indicators, based on publicly available data. For example, the most commonly used indicator for human capital is labor costs (Sydler et al., 2014; Pulic, 2000; Tseng and Goo, 2005; Edvinsson, 1997); for structural capital is selling, general and administration or R\&D expenses (Edvinsson and Malone, 1997; Roos and Roos, 1997; Stewart, 1997; Van Buren, 1999; Sydler et al., 2014); and for relational capital commercial expenses (Edvinsson and Malone, 1997; Wu and Tsai, 2005; Johnson and Soenen, 2003). The main limitation of this approach is that indicators from financial reporting do not reflect the real value of the different elements of IC, as balance sheets and income statements are prepared on the basis of conservative accrual accounting that does not reflect real expectations of the market.

The third approach suggests using a questionnaire to estimate IC. St-Pierre and Audet (2011) argue that such a method may provide deeper and broader insight into the studied phenomenon, so we chose to follow this. The survey was developed by an international team of experts, as part of an international project, aimed to study the impact of IC on performance in different countries and validated in Finland (Inkinen et al., 2014). The survey was subsequently translated into Russian.

\section{Independent variables}

Measures for IC categories were adapted from the previous literature where applicable and also developed by the lead project team. The ideas for the internal relational capital scale were adapted from Kianto (2008) and Yang and Lin (2009); the external relational capital scale from Kianto (2008); and the structural capital scale from (Kianto, 2008; Kianto et al., 2010). The scale for human capital was based on the conceptual ideas of Bontis (1998) and Yang and Lin (2009).

\section{Organizational performance}

The measure for organizational performance was borrowed from Delaney and Huselid (1996).

All of the measures were based on a five-point Likert scale (1-strongly disagree, 5-strongly agree).

The research includes a two-stage analysis. First, an exploratory factor analysis was performed to check for the reliability and validity of the measurement scales (Hurley et al., 1997). Then a regression analysis was applied to define the impact of different IC 
elements (human capital (HC), relational capital (RC) and structural capital (SC)) on Evidence from organizational performance $(\mathrm{OP})$.

The regression model is formulated as follows:

$$
O P=\beta_{0}+\beta_{1} \times H C+\beta_{2} \times R C+\beta_{3} \times S C+\beta_{4} \times E m p+\varepsilon_{0}
$$

where $\beta_{0}, \beta_{1}, \beta_{2}, \beta_{3}, \beta_{4}$ are the unknown coefficients of the model, $\varepsilon_{0}$ the error, factors, not included in the model. The size of the company (number of employees) was used as context a control variable.

\section{Results}

As a first step of the analysis, exploratory factor analysis was performed to check for the reliability and validity of the measurement scales (Hurley et al., 1997). Table V introduces the scale items with respective factor loadings and internal consistencies of the scales. Cronbach's $\alpha$ of all scales are over 0.7, indicating good internal consistency and validity of the scales.

Table VI presents descriptive statistics for resulting latent variables.

As a next step, regression analysis was performed to test the impact of the different IC elements on organizational performance.

\begin{tabular}{lc}
\hline Survey items & Factor loadings \\
\hline $\begin{array}{l}\text { Performance: compared to other companies in this industry sector, how do you } \\
\text { think your company has succeeded in the following areas over the past year? }\end{array}$ & Cronbach's $\alpha=0.908$ \\
Net sales growth & 0.904 \\
Profitability & 0.868 \\
Market share & 0.871 \\
Human capital: to what extent do the following statements on employee & Cronbach's $\alpha=0.824$ \\
competence apply to your company? & 0.759 \\
Our employees are highly skilled at their jobs & 0.695 \\
Our employees are highly motivated in their work & 0.852 \\
Our employees have a high level of expertise & Cronbach's $\alpha=0.752$ \\
Structural capital: to what extent do the following statements on internal & \\
structures apply to your company? & 0.586 \\
Our company has efficient and relevant information systems to support & 0.65 \\
business operations & 0.578 \\
Our company has tools and facilities to support cooperation between employees & 0.751 \\
Our company has a great deal of useful knowledge in documents and databases & \\
Existing documents and solutions are easily accessible & Cronbach's $\alpha=0.832$ \\
Relational capital: to what extent do the following statements apply to your & \\
company? & \\
Different units and functions within our company - such as R\&D, marketing & \\
and production - understand each other well & 0.598 \\
Our employees frequently collaborate to solve problems & 0.751 \\
Internal cooperation in our company runs smoothly & 0.703 \\
Our company and its external stakeholders - such as customers, suppliers and & \\
partners - understand each other well & 0.633 \\
$\begin{array}{l}\text { Our company and its external stakeholders frequently collaborate to solve problems } \\
\text { Cooperation between our company and its external stakeholders runs smoothly }\end{array}$ & 0.679 \\
\hline & 0.761 \\
\hline
\end{tabular}


$\mathrm{JIC}$

17,2

406

The results are provided in Table VII. They indicate that only structural capital and human capital have an impact on organizational performance in the sample, with $\beta$-coefficients 0.313 and 0.249 , respectively. Relational capital has no impact on performance. The model explains 25.6 percent of variation in organizational performance. Therefore, $H 1$ is supported (as human capital has lower impact on performance, compared to structural capital), while $H 2$ and $H 3$ are refuted.

\section{Discussion}

This study aimed to examine the influence of the three elements of IC on companies' performance, using data from Russian manufacturing firms. The findings demonstrate that structural and human capitals positively influence organizational performance, explaining a quarter of its variation, while relational capital does not. These findings are somewhat different both from those of previous studies on the IC-performance link in developed markets, which typically found that human capital is the most influential element of IC and from the context-informed hypotheses. Indeed, in the light of the importance of the networking and relationships with the "right" people for doing business in Russia (Lonkila, 2011; Puffer and McCarthy, 2011), it was quite unpredictable that relational capital does not relate to financial results in Russian manufacturing companies. Several reasons may explain such discrepancies.

First, it could be that the peculiarities of the Russian context have led to a situation where most companies have relatively high relational capital and thus it does not provide a unique competitive advantage. Indeed, a closer look into the data suggests that this element of IC has a high mean and the lowest standard deviation in the sample and on its own is positively correlated with performance (Table VI). The significance of this factor is eliminated when all elements of IC are included in one model. In other words, relational capital might be a prerequisite for being able to "play the game" in the Russian context, but not sufficient to outperform others. Furthermore, there might be some interaction effects between different elements of IC that lead to such results (e.g. see Ennen and Richter, 2010).

Second, some prior research has found that IC has a delayed effect on organizational performance (e.g. Väisänen et al., 2007). This argument is particularly relevant for relational capital, as it takes time to develop the necessary relations with external

\begin{tabular}{llcccccr}
\hline & & \multicolumn{7}{c}{ Correlations } \\
No. & Latent variable & Mean & SD & 1 & 2 & 3 & 4 \\
\hline 1 & Human capital & 4.12 & 0.71 & 1 & & \\
2 & Relational capital & 4.08 & 0.60 & $0.563^{* * *}$ & 1 & \\
3 & Structural capital & 3.83 & 0.74 & $0.583^{* * *}$ & $0.490^{* * * *}$ & 1 & \\
4 & Organizational performance & 3.24 & 1.06 & $0.444^{* * *}$ & $0.309^{* * *}$ & $0.468^{* * * *}$ & 1 \\
Note: ***Correlation is significant at the 0.000 level (two-tailed) & & & \\
\hline
\end{tabular}

Independent variables Constant Human capital Relational capital Structural capital N_employees

Table VI.

Descriptive statistics for the study variables

\begin{tabular}{lrllll}
\hline$B$ & -0.362 & 0.249 & 0.016 & 0.313 & 0.058 \\
Significance & 0.717 & 0.001 & 0.819 & 0.000 & 0.307 \\
Adjusted $R^{2}$ & 0.256 & & & & \\
\hline
\end{tabular}


agents and stakeholders. Therefore, this component of IC might still have a (significant) effect on the performance of Russian companies when treated over a longer time perspective.

Third, the relatively high significance of structural capital, contrary to the $H 2$, might be explained by the fact that in the sample, in contrast to relational capital, structural capital was the least developed element of IC, with the lowest mean and the highest standard deviation. This means that structural capital is indeed relatively low among Russian companies, in line with the authors' arguments in the theoretical section. However, for those companies who are able to develop more of it, its rarity gives them a special advantage.

Finally, there might be some industry differences in the way that IC contributes to performance (e.g. Kianto et al., 2010). For example, the strongest role of structural capital in the study might be explained by the fact that the data comes from manufacturing companies. This idea is supported by findings from different countries. For example, Bontis et al. (2000) found that structural capital was the most important element of IC influencing financial results in non-service companies. In contrast, human capital is identified as the main factor influencing companies' financial performance in pharmaceutical companies (Bollen, 2005; Kamath, 2008; Komnenic and Pokrajcic, 2012; Maditinos et al., 2011) where employees play a very important role in innovations that then influence the companies' results. Further, relational capital was found to be the most important element for telecommunications companies (Garanina, 2010; Suraj and Bontis, 2012), as clients' loyalty lies at the base of the profitability of such companies. To summarize, previous research suggests that industry-specific influences which IC element is the most influential in defining company results (Cabrita and Bontis, 2008). These considerations, paired with ideas discussed in the theoretical section, lead to further questions: what level of context matters more for the relationship between IC elements and performance: that of the industry or that of the national ecosystem? Or how do these two levels of context interact?

\section{Conclusions}

This paper aimed to analyze how various elements of IC affect organizational performance in the particular context of Russian manufacturing companies. The findings, based on the survey of 240 companies, demonstrate that structural and human capitals positively influence organizational performance, explaining a quarter of its variation, while relational capital does not. These results might be explained by the peculiarities of the Russian context, where high relational capital is common and thus it does not provide a unique competitive advantage.

Some future research avenues stem from the limitations of this study and from the considerations raised in the discussion section. Some of the limitations are related to the nature of the data collected, with subjective performance measures collected at the same time as the data on IC elements. This did not allow testing long-term effects of IC, particularly, that of relational capital, as discussed above. This hypothesis can be examined in future studies, using time-lagged performance data.

From the academic perspective the paper contributes to further development of IC theory by investigating its application in the new institutional and cultural context of Russia.

From the practice perspective, it is particularly interesting that structural capital, that was found in the study to have the strongest impact on organizational performance, was evaluated by survey participants as being the least developed of 
JIC

17,2

408

the IC elements in their companies (see Table VI). Therefore the authors suggest that the core managerial implication of this study urges managers of Russian manufacturing companies to pay particular attention to developing their structural capital by providing relevant practices, tools and opportunities that would ensure that knowledge is efficiently acquired, created, shared, documented and applied. These might include having a clear knowledge strategy (e.g. Zack, 1999) and implementing information systems and tools (e.g. Leonardi, 2014), training, rotation, remuneration policies, job design and other HR practices (e.g. Cabrera and Cabrera, 2005; Foss et al., 2009). Coupled with the observation that human capital (despite being the most developed of the elements of IC, see Table VI) is always at risk of leaving an organization, developing structural capital might be particularly important as it becomes critical for retaining intangible assets in the organization.

Further studies may proceed with analysis of the objective performance measures, or a combination of both subjective and objective ones, to examine the link between IC and performance in a more comprehensive manner.

Extending the discussion of various measurement methods for IC, namely, financial proxies vs surveys, future studies might incorporate both types of measure and contrast their accuracy in measuring IC components, as well as their predictive value for organizational performance. It would be interesting to contrast these measures in different contexts, in particular in those where official financial reporting has been blamed for not reflecting the real status quo of the companies and where different accounting approaches are widely used for financial management.

Yet one more interesting area to study further is to explore the peculiarities of the different sectors or industries, embedded in different national contexts. For example, how does the link between IC elements and performance work in service firms? Some findings from developed markets suggest that human capital might have the strongest impact in this sector (e.g. Kianto et al., 2010); would this relationship hold similarly in the context of emerging markets that struggle with a lack of qualified personnel and the brain drain? Extending such arguments to various contexts will contribute to a more nuanced understanding of the role of IC and thus will increase the efficiency of management.

\section{References}

Andreeva, T. and Ikhilchik, I. (2011), "Applicability of the SECI model of knowledge creation in Russian cultural context: theoretical analysis”, Knowledge and Process Management, Vol. 18 No. 1, pp. 56-66.

Andreeva, T. and Kianto, A. (2012), "Does knowledge management really matter? Linking knowledge management practices, competitiveness and economic performance", Journal of Knowledge Management, Vol. 16 No. 4, pp. 617-636.

Andreeva, T., Garanina, T. and Ryzhko, A. (2015), “Upravlenie znanijami I intellectualny kapiral v rossijskih promyshlennikh kompanijakh: rezultaty issledovanija - 2015 (Knowledge management and intellectual capital in Russian companies: Research findings - 2015)", research report, Graduate School of Management, St Petersburg University, St Petersburg, available at: www.gsom.pu.ru (accessed September 15, 2015).

Ardichvili, A. and Dirani, K. (2005), "Human capital practices of Russian enterprises", Human Resource Development International, Vol. 8 No. 4, pp. 403-418.

Bayburina, J.R. and Golovko, T.V. (2008), "Empiricheskoe issledovanie intellektual'noj stoimosti krupnyh rossijskih kompanij i faktorov ee rosta”, Korporativnye finansy, Vol. 2 No. 6, pp. 5-19. 
Bollen, L.P. (2005), "Linking intellectual capital and intellectual property to company Evidence from performance", Management Decision, Vol. 43 No. 9, pp. 1161-1185.

Bontis, N. (1998), "Intellectual capital: an exploratory study that develops measures and models", Management Decision, Vol. 36 No. 2, pp. 63-76.

Bontis, N., Keow, W.C.C. and Richardson, S. (2000), "Intellectual capital and business performance in Malaysian industries", Journal of Intellectual Capital, Vol. 1 No. 1, pp. 85-100.

Bykova, A.A. and Molodchik, M.A. (2011), "Vlijanie intellektual'nogo kapitala na rezul'taty dejatel'nosti kompanii”, Vestnik SPbGU, Serija Menedzhment, Vol. 1, pp. 27-55.

Cabrera, E.F. and Cabrera, A. (2005), "Fostering knowledge sharing through people management practices", International Journal of Human Resource Management, Vol. 16 No. 5, pp. 720-735.

Cabrita, M.D.R. and Bontis, N. (2008), "Intellectual capital and business performance in the portuguese banking industry", International Journal Technology Management, Vol. 43 Nos 1-3, pp. 212-237.

Clarke, S. and Metalina, T. (2000), "Training in the new private sector in Russia”, International Journal of Human Resource Management, Vol. 11 No. 1, pp. 19-36.

Coombs, J.E. and Bierly, P.E. (2006), "Measuring technological capability and performance", R\&D Management, Vol. 36 No. 4, pp. 421-437.

Delaney, J. and Huselid, M.A. (1996), "The impact of human resource management practices on perceptions of organizational performance", Academy of Management Journal, Vol. 39 No. 4, pp. 949-969.

Dittrich, M., Giljum, S., Polzin, C., Lutter, S. and Bringezu, S. (2011), "Resource use and resource efficiency in emerging economies: trends over the past 20 years", Working Paper No. 12, Sustainable Europe Research Institute (SERI), Vienna, pp. 1-38, available at: http://seri.at/ wp-content/uploads/2011/03/SERI_WorkingPaper12.pdf (accessed October 20, 2015).

Economist (2008), "People for growth: the talent challenge in emerging markets", Economist, a report from the Economist Intelligence Unit, London, New York, NY and Hong Kong, pp. 1-20, available at: http://graphics.eiu.com/upload/People_for_growth.pdf (accessed October 15, 2015).

Edvinsson, L. (1997), "Developing intellectual capital at Skandia”, Long Range Planning, Vol. 30 No. 3, pp. 366-373.

Edvinsson, L. and Malone, M. (1997), Intellectual Capital: Realising Your Company's True Value by Finding its Hidden Brainpower, Harper Collins, New York, NY.

Ennen, E. and Richter, A. (2010), "The whole is more than the sum of its parts - or is it? A review of the empirical literature on complementarities in organizations", Journal of Management, Vol. 36 No. 1, pp. 207-233.

FASB (2007), "Financial Accounting Standards Board report", pp. 1-81, available at: www.fasb. org/cs/BlobServer?blobkey=id\&blobwhere $=1175823288072 \&$ blobheader=application $\%$ 2Fpdf\&blobcol=urldata\&blobtable=MungoBlobs (accessed October 15, 2015).

F-Jardón, C.M. and Martos, M.S. (2009), "Intellectual capital and performance in wood industries of Argentina”, Journal of Intellectual Capital, Vol. 10 No. 4, pp. 600-616.

Foss, N.J., Minbaeva, D.B., Pedersen, T. and Reinholt, M. (2009), "Encouraging knowledge sharing among employees: how job design matters", Human Resource Management, Vol. 48 No. 6, pp. 871-893.

Furman, J.L., Porter, M.E. and Stern, S. (2002), "The determinants of national innovative capacity”, Research Policy, Vol. 11 No. 6, pp. 899-933. 
JIC

17,2

Garanina, T. (2010), "Nematerialnye aktivy i intellektualnyi kapital: rol v sozdanii cennosti kompanii”, Vestnik SPbSU. Seria Menedzhment, No. 2, pp. 17-44.

Garanina, T. (2011), "Intellectual capital structure and value creation of a company: evidence from Russian companies", Open Journal of Economic Research, Vol. 1 No. 2, pp. 22-34.

Gurkov, I. and Zelenova, O. (2009), "Human resource management in Russia", in Morley, M., Heraty, N. and Michailova, S. (Eds), Managing Human Resources in Central and Eastern Europe, Routledge Chapman and Hall, London, pp. 150-188.

Gurkov, I., Zelenova, O. and Saidov, Z. (2012a), "Mutation of HRM practices in Russia: an application of CRANET methodology", International Journal of Human Resource Management, Vol. 23 No. 7, pp. 1289-1302.

Gurkov, I., Morgunov, E., Settles, A. and Zelenova, O. (2012b), "HRM in Russia over a century of storm and turmoil: a tale of unrealized dreams", in Kaufman, B.E. (Ed.), Unity and Diversity: The Historical Development of HRM Across Nations, Edward Elgar.

Guthrie, J. (2001), "The management, measurement and the reporting of intellectual capital", Journal of Intellectual Capital, Vol. 2 No. 1, pp. 27-41.

Hurley, A.E., Scandura, T.A., Schriesheim, C.A., Brannick, M.T., Seers, A., Vandeberg, R.J. and Williams, L.J. (1997), "Exploratory and confirmatory factor analysis: guidelines, issues and alternatives", Journal of Organizational Behavior, Vol. 18 No. 6, pp. 667-683.

IFAC (1998), The Measurement and Management of Intellectual Capital: An Introduction, IFAC, Study 7.

Inkinen, H. (2015), "Review of empirical research on intellectual capital and firm performance", Journal of Intellectual Capital, Vol. 16 No. 3, pp. 518-565.

Inkinen, H., Kianto, A., Vanhala, M. and Ritala, P. (2014), "Intellectual capital and performance Empirical findings from Finnish firms", paper presented at the International Forum on Knowledge Asset Dynamics (IFKAD), 11-13 June, Matera, available at: http://www. knowledgeasset.org/Proceedings/ (accessed October 15, 2015).

Johns, G. (2006), "The essential impact of context on organizational behavior", Academy of Management Review, Vol. 31 No. 2, pp. 386-408.

Johnson, R. and Soenen, L. (2003), "Indicators of successful companies”, European Management Journal, Vol. 21 No. 3, pp. 364-369.

Kamath, G.B. (2008), "Intellectual capital and corporate performance in Indian pharmaceutical industry", Journal of Intellectual Capital, Vol. 9 No. 4, pp. 684-704.

Kianto, A. (2008), "Development and validation of a survey instrument for measuring organizational renewal capability”, International Journal of Technology Management, Vol. 42 Nos 1/2, pp. 69-88.

Kianto, A., Hurmelinna-Laukkanen, P. and Ritala, P. (2010), "Intellectual capital in service-and product-oriented companies", Journal of Intellectual Capital, Vol. 11 No. 3, pp. 305-325.

Komnenic, B. and Pokrajcic, D. (2012), "Intellectual capital and corporate performance of MNCs in Serbia”, Journal of Intellectual Capital, Vol. 13 No. 1, pp. 106-119.

Ledeneva, A.V. (1998), Russia's Economy of Favors: Blat, Networking and Informal Exchange, Cambridge University Press, Cambridge.

Leonardi, P. (2014), "Social media at work: toward a theory of communication visibility", Information Systems Research, Vol. 25 No. 4, pp. 796-816.

Lonkila, M. (2011), Networks in the Russian Market Economy, Palgrave Macmillan, New York, NY. 
McCarthy, D., Puffer,, S.M., Dunlap-Hinkler, D. and Jaeger, A. (2012), “A stakeholder approach to Evidence from the ethicality of BRIC-firm managers' use of favors", Journal of Business Ethics, Vol. 109 No. 1, pp. 27-38.

Maditinos, D., Chatzoudes, D., Tsairidis, C. and Theriou, G. (2011), "The impact of intellectual capital on firms' market value and financial performance", Journal of Intellectual Capital, Vol. 12 No. 1, pp. 132-151.

Marr, B. and Roos, G. (2005), "A strategy perspective on intellectual capital”, in Marr, B. (Ed.), Perspectives on Intellectual Capital: Multidisciplinary Insights into Management, Measurement and Reporting, Butterworth-Heinemann, Oxford, pp. 28-41.

May, R.C. and Stewart, W.H. (2013), "Building theory with BRICs: Russia's contribution to knowledge sharing theory”, Critical Perspectives on International Business, Vol. 9 Nos 1-2, pp. 147-172.

May, R.C., Stewart, W.H., Puffer, S.M., McCarthy, D.J. and Ledgerwood, D.E. (2011), "Predictors of individual knowledge acquisition commitment in a post-soviet setting", Management International Review, Vol. 51 No. 5, pp. 697-798.

Michailova, S. (2011), "Contextualizing in international business research: why do we need more of it and how can we be better at it?", Scandinavian Journal of Management, Vol. 27 No. 1, pp. 129-139.

Michailova, S. and Husted, K. (2003), "Knowledge-sharing hostility in Russian firms", California Management Review, Vol. 45 No. 3, pp. 59-77.

Michailova, S. and Hutchings, K. (2006), "National cultural influences on knowledge sharing: a comparison of China and Russia", Journal of Management Studies, Vol. 43 No. 3, pp. 383-405.

Michailova, S. and Worm, V. (2003), "Personal networking in Russia and China: blat and guanxi”, European Management Journal, Vol. 21 No. 4, pp. 509-519.

Molodchik, M.A. and Nursubina, J.S. (2012), "Innovacii i intellektual'nyj kapital kompanii: analiz panel'nyh dannyh", $V$ sbornike: Sovremennye strategii innovacionnogo razvitija. Trinadcatye Drukerovskie chtenija, Pod redakciej R.M, Nizhegorodceva, Novocherkassk, pp. 231-237.

OECD (2012), "Education at a glance: Russian federation", available at: www.oecd.org/edu/ EAG2012\%20-\%20Country\%20note\%20-\%20Russian\%20Federation.pdf (accessed October 15, 2015).

PricewaterhouseCoopers (2014), "A new vision for growth: key trends in human capital”, available at: www.pwc.com/gx/en/hr-management-services/pdf/pwc-key-trends-in-humancapital-2014.pdf (accessed October 15, 2015).

Puffer, S.M. and McCarthy, D.J. (2011), "Two decades of Russian business and management research: an institutional theory perspective", Academy of Management Perspectives, Vol. 25 No. 2, pp. 21-36.

Pulic, A. (2000), "VAIC: an accounting tool for IC management", International Journal of Technology Management, Vol. 20 Nos 5-8, pp. 702-714.

Roos, G. and Roos, J. (1997), "Measuring your company's intellectual performance”, Long Range Planning, Vol. 30 No. 3, pp. 413-426.

Salmi, A. and Bäckman, J. (1999), "Personal relations in Russian business: two circles", Institutions and Post-Socialist Transition, B-22, pp. 139-168.

Sergeeva, A. and Andreeva, T. (forthcoming), "Knowledge sharing: bringing the context back in", Journal of Management Inquiry, available at: http:/jmi.sagepub.com/content/early/2015/ 12/09/1056492615618271.abstract

Stewart, T. (1997), Intellectual Capital: The New Wealth of Organizations, Doubleday, New York, NY. 
$\mathrm{JIC}$

17,2

St-Pierre, J. and Audet, J. (2011), "Intangible assets and performance: analysis on manufacturing SMEs", Journal of Intellectual Capital, Vol. 12 No. 2, pp. 202-223.

Subramaniam, M. and Youndt, M. (2005), "The influence of intellectual capital on the types of innovative capabilities", Academy of Management Journal, Vol. 48 No. 3, pp. 450-463.

Suraj, O.A. and Bontis, N. (2012), "Managing intellectual capital in Nigerian telecommunications companies", Journal of Intellectual Capital, Vol. 13 No. 2, pp. 262-282.

Sveiby, K.E. (1997), The New Organizational Wealth: Managing and Measuring Knowledge Based Assets, Berrett Koehler, San Francisco, CA.

Sydler, R., Haefliger, S. and Pruksa, R. (2014), "Measuring intellectual capital with financial figures: can we predict firm profitability?", European Management Journal, Vol. 32 No. 2, pp. 244-259.

Tomchuk, D., Perskij, J. and Sevodina, V (2013), "Intellektual'nyj kapital i rentabel'nost' predprijatija: harakteristika i ocenka”, Resursy, informacija, snabzhenie, konkurencija, No. 2, pp. 330-334.

Tovstiga, G. and Tulugurova, E. (2007), "Intellectual capital practices and performance in Russian enterprises”, Journal of Intellectual Capital, Vol. 8 No. 4, pp. 695-707.

Tseng, C.Y. and Goo, Y.J. (2005), "Intellectual capital and corporate value in an emerging economy: empirical study of Taiwanese manufacturers", R\&D Management, Vol. 35 No. 2, pp. 187-201.

Väisänen, J., Kujansivu, P. and Lönnqvist, A. (2007), "Effects of intellectual capital investments on productivity and profitability", International Journal of Learning and Intellectual Capital, Vol. 4 No. 4, pp. 377-391.

Van Buren, M.E. (1999), "A yardstick for knowledge management: American society for training and development, Inc.", Training and Development, Vol. 53 No. 5, pp. 71-78.

Whetten, D.A. (2009), "An examination of the interface between context and theory applied to the study of Chinese organizations", Management and Organization Review, Vol. 5 No. 1, pp. 29-55.

Wu, W.Y. and Tsai, H.J. (2005), "Impact of social capital and business operation mode on intellectual capital and knowledge management", International Journal of Technology Management, Vol. 3 Nos 1-2, pp. 147-171.

Yang, C. and Lin, C. (2009), "Does intellectual capital mediate the relationship between HRM and organizational performance? Perspective of a healthcare industry in Taiwan", International Journal of Human Resource Management, Vol. 20 No. 9, pp. 1965-1984.

Zack, M.H. (1999), "Developing a knowledge strategy”, California Management Review, Vol. 41 No. 3, pp. 125-145.

\section{Further reading}

Molodchik, M. and Teplykh, G. (2013), "Obosnovanie strukturnogo soderzhaniyz intellectualnogo kapitala kompanii v ramkah cennostno-orientirovannogo podhoda”, Financy i kredit, Vol. 4 No. 532, pp. $73-84$.

\section{Corresponding author}

Tatiana Garanina can be contacted at: garanina@gsom.pu.ru

For instructions on how to order reprints of this article, please visit our website:

www.emeraldgrouppublishing.com/licensing/reprints.htm

Or contact us for further details: permissions@emeraldinsight.com 